\title{
RELIGIOUS BUILDINGS IN THE REPUBLIC OF MACEDONIA AND THEIR SIGNIFICANCE AS TOURIST RESOURCES
}

\author{
Meri Nickova', \\ Dejan Nakovski', \\ Goran Apostolovski ${ }^{1}$ \\ ${ }^{1}$ University of Tourism and Management \\ in Skopje, \\ Skopje, Macedonia
}

\begin{abstract}
:
Tourist movements or flows are affected by presence, quantity and spatial distribution of travel motifs and tourist resources within a destination. This statement is particularly important in the sites which are not traditional tourist sites, not recognized and developed as tourist destinations, as is the case with the territory of the Republic of Macedonia. In this context, the aim of this paper is to present and classify religious tourism resources as important tourist motifs, which can contribute to the attractiveness and the offer of tourist destinations.
\end{abstract}

Keywords:

tourist motives, religious tourism, destination, tourist flows.

\section{INTRODUCTION}

Alternative forms of tourism should be the focus of future tourism development in the Republic of Macedonia, since the country has numerous tourist resources for this type of tourism.

The authors' opinion is that alternative forms of tourism should be promoted. This was also stated in the draft plan of the National Strategy for Tourism Development, as follows "the future development of tourism in the Republic Macedonia should be based on four main pillars: Skopje, Ohrid lake, Macedonia's culture and experiences in nature" (Kohl \& Partner, 2015). When observing various types of alternative forms of tourism, the religious tourism is distinguished as an important type of tourist movement, and it is understood as "a set of relationships and service activities which predominantly satisfy spiritual needs, but also cultural and social needs arising from religious determinations of tourists" (Budinovski, 2009).

This definition of religious tourism is acceptable to the authors of this paper, as it states that religious tourism is closely linked to cultural tourism. Tourists who participate in religious tourism acquire cultural education, apart from the spiritual values. The basic motive for travels of religious tourists is religion, but there are some differences in terms of their motives. They visit religious buildings and places to fulfil of their religious obligations and rituals and in this case, the travel is dominated by the religion. The motives for visiting religious buildings could also be historical, cultural, architectural or artistic values, and cultural and educational aspects of the tourist movement predominate in this case. 
In order to include religious tourism in the tourist offer of the contemporary tourist market, it is essential to understand motives of the present-day religious tourist, which Hrabovski-Tomic describe in the following way: "Religious tourists do not travel solely to holy places characteristic of their own religion, but travel due to interest and curiosity in the context of enriching their education and culture" (Hrabovski-Tomic, 2008).

Previous observations of this subject by various authors have mostly discussed the phenomenon of the religious tourism and the religious tours, but the authors of this paper intend to emphasize the relevance of the religious tourism and highlight the importance of primary tourism resources for development of the religious tourism in the country.

\section{METHODOLOGY}

The basic theoretical assumption in the paper is that the development of the religious tourism in the country is supported by religious buildings, according to their destination attributes to attract tourists and encourage tourist movement.

The methodology of data processing is very important for proper tourism planning, so according to Panov "the methods that are undertaken represent a very important and integral part on which further proceedings in the implementation will depend" (Panov, 2006). In the preparation of the scientific paper, the secondary data were used i.e. the official data available in the statistical bulletins of the State Statistical Office and in the official action plans for tourism development. Several scientific methods were used, applicable to research in the field of tourism.

\section{RESULTS AND DISCUSSION}

In the National Strategy for Tourism Development in the country (Kohl \& Partner, 2015), the main tourist attractions in the country are divided into two groups, natural attractions and cultural sites. The cultural sites, among other attractions, include churches, mosques and monasteries. Although there are numerous religious buildings of Orthodox Christianity and the Islamic religion on the territory of the Republic of Macedonia, they do not have the same religious or spiritual importance. "There are over 150 preserved monasteries in Macedonia, most of which have only local character..." (Girevski 2008) and out of this number, around twenty churches and monasteries are located in the south-west tourist region, in the area of Ohrid and Struga (Ministry of Culture 2012). In view of the fact that this region has the most active tourism, with more than $50 \%$ of the realized tourist arrivals and overnight stays compared to the rest of country, it is expected that these religious buildings are the most important and the most visited by tourists. However, it is necessary to present other important religious sites located outside of the south-west tourist area, which have sufficient attractive attributes for the religious tourism development. The authors used, as parameters, data from the list of the Cultural Heritage Protection Office at the Ministry of Culture of the Republic of Macedonia to determine the value of religious and cultural sites.

In the Table 1, some of the religious buildings placed under protection as cultural heritage are listed, while the following text provides basic information on the most important sites.

Table 1. Religious buildings protected by the law

\begin{tabular}{|c|c|}
\hline Place / location & Religious object \\
\hline \multirow{12}{*}{ Bitola } & "Kaimakchalan” Church \\
\hline & “St. Demetrius" Church \\
\hline & "Virgin Mary" Church \\
\hline & "Kodzha Kadi” Mosque \\
\hline & "Hamza Bey” Mosque \\
\hline & "Aydar Kadi” Mosque \\
\hline & "Yeni" Mosque \\
\hline & "Ishak Celebi" Mosque \\
\hline & "Virgin Mary" Church, Velušina \\
\hline & “Transfiguration" Church \\
\hline & "St. Petka" Church \\
\hline & “Archangel Michael” Church \\
\hline
\end{tabular}




\begin{tabular}{|c|c|}
\hline \multirow{12}{*}{ Makedonski Brod } & “Trinity" Church \\
\hline & “Archangel Michael” Church \\
\hline & "Virgin Mary" Church \\
\hline & "St. Nicholas" Church \\
\hline & "St. Athanasius" Church \\
\hline & "Presentation of the Virgin" Church \\
\hline & "St. Peter and Paul" Church \\
\hline & "St. Nicholas" Church \\
\hline & "Archangel Gabriel" Church \\
\hline & "St. Athanasius" Church \\
\hline & "Virgin Mary" Church \\
\hline & "St. Demetrius" Church \\
\hline \multirow{2}{*}{ Gevgelija } & “St. Demetrius" Church \\
\hline & "St. Elias" Church \\
\hline \multirow{3}{*}{ Rostusha } & "St. John the Baptist" Monastery \\
\hline & "St. George the Victorious" Church \\
\hline & "St. Peter and Paul" Church \\
\hline \multirow{2}{*}{ Debar } & "St. Petka" Church \\
\hline & "Inkjar” Mosque \\
\hline \multirow{3}{*}{ Delcevo } & "St. Constantine and Helena" Church \\
\hline & "St. Archangel Michael" Church \\
\hline & "St. Petka" Church \\
\hline \multirow{3}{*}{ Kriva Palanka } & "Joachim Osogovski" Monastery \\
\hline & "St. Demetrius" Church \\
\hline & "St. Nicholas" Church \\
\hline \multirow{3}{*}{ Probistip } & “Gavril Lesnovski” Monastery \\
\hline & "Assumption of the Virgin" Church \\
\hline & "St. Tryphon-Pirog” Church \\
\hline
\end{tabular}

Source: List of protected goods. Office for Protection of Cultural Heritage.

Monastery of the Holy Archangels, Kuceviste. The monastery church, dedicated to the Holy Archangels Michael and Gabriel, is located near the village Kuceviste, at Skopska Crna Gora. It was built during the reign of the King Marko between the Marica battle in 1371 and the Battle of Kosovo in 1389. In the 19th century, the monastery experienced its revival: it became theological school centre with a rich library and valuable objects of worship, got a new iconostasis in 1843 and icons in 1846 . The activities in the monastery were associated with the abbot, the monk Misail born in Tetovo, in the village Kopanica.

Church of the Holy Saviour, Skopje. The church, dedicated to Christ's ascension to heaven, is located under the walls of the Skopje Fortress, within the limits of the Old Bazaar, hidden behind by the walls and dug several meters below the ground level. The temple was reconstructed in the first decades of the 19th century, not in the best conditions for building monumental Christian buildings, especially when it comes to the busiest area of the city core - the bazaar. The original temple was built in the late 16 th or the early 17 th century, with frescoes representations of the archangels Michael and Gabriel and medallions of martyrs in the south wall of the ancient temple. The double row wood carved iconostasis is one of the first ornaments of the Mijak woodcarving group headed by the masters Petre Filipovski from Gari and Makarij Frckovski from Galicnik, who worked in the period between 1819 and 1824 .

Church of St. George, Mlado Nagoricane. It is located in the medieval area of Zegligovo, northeast of Kumanovo to the road to Kriva Palanka. It is one 
of the most representative and the most monumental Christian buildings from the time of the Ottoman rule in Macedonia. Mlado Nagorichane area is sometimes called Little Mount Athos due to the concentration of many churches, today mostly destroyed. According to the latest research, the temple dates from the second half on the 16 century.

Church of St. Nicholas, Kumanovo. Constructed in 1851 , it is basically a copy of the church built ten years earlier by Damyanov from Veles - St. Panteleimon. In the upper parts of the central nave, almost twice the external sides and higher than them, four cupolas are "hidden" and their domes are not visible from the outside. On the southern, northern and western sides, there are porches that close the central space of the church and contribute to the massiveness and the vastness of the complex.

Monastery of St. Joachim Osogovski, Kriva Palanka. On the slopes of the Osogovo mountains, near the border town of Kriva Palanka, the monastery complex is located, which is dedicated to the hermit St. Joachim Osogovski, from 10th century, who is considered to be a pioneer. The monastery is known as Sarandopor, after the place where it was built. From the lives of Joachim Osogovski, we learned that the first church was built by the monk Theophanes, during the reign of the Byzantine Emperor, Manojlo Comnenus (1143-1180). Today there are two temples. The small old church is dedicated to the feast of the Nativity of the Virgin, which existed since 12 th century, probably restored in the early 14 th century by the King Milutin. The renewed temple of King Milutin was built in the Byzantine style, with stone blocks and horizontal and vertical brick friezes. The dome set on a high drum was built after partial destruction of the temple in the 19th century. The building has a separate entrance for deacons on the southeast and the porch on the west side. Today's appearance is due to reconstructions during 1980s which included new paintings in the central space (nave). The porch is completely painted by "the last Macedonian painter" and "the first modern painter" - Dimitar Andonov Papradiski during several years of his stay in the monastery, working at the same time on the church and other great cathedrals. There are mostly scenes devoted to the patron of the temple: Mary with Jesus Christ (over the entrance to the nave), Mary with Joachim Osogovski and Mary the life-giving Easterner, near the spring with healing water in the northeast, the Presentation of the Virgin in the Temple and Queen Mary with Christ the King, in the central blind dome. The southern blind dome is dedicated to St. John the Baptist and the northern to St. Joachim Osogovski. The cathedral of St. Joachim was built south of the Virgin Mary church in the period 1847-1851. It is a masterpiece of one of the most famous Balkan builders of the 19th century, Andrey Damyanov from Veles.

Church of St. Demetrius, Bitola. In place of the modest chapel from 1726, the church dedicated to St. Demetrius, consisting of a spacious nave and two aisles, was built in 1830 in the central part of Bitola. The temple was built low to the ground respecting the Turkish ban on raising large Christian buildings, especially in urban areas. Inside, some naves have multi-storey galleries and chapels on the east side, dedicated to St. Transfiguration (south) and St. Gregory (north). The iconostases of these chapels (especially the one on the south side) are formed from parts that adorned the iconostasis of the former temple, in shallow ornate and gilded carving of zoomorphic and floral motifs. Some icons of the iconostasis are exhibited today at the Museum of Macedonia in Skopje, which were done by a famous painter of the 18th century, David from the Albanian village Selenice, one of the biggest supporters of the Mount Athos painting tradition, with the model of the Protaton monastery.

Monastery of St. John Bigorski. Thirty kilometres from Debar, overhanging the rapid waters of the river Radika, cut in the cliffs of Mount Bistra, it is an impressive building which is the centre of almost nine centuries long monastic life - the monastery dedicated to St. John the Baptist. According to the legend, the monastery was founded in 1020. It underwent great restoration in the early 19th century and today it still hides traces of its rich history. The exclusive pieces of the monastery treasury exhibited in the former women's dining room include: miraculous icon of the patron of the temple from the 17 th century, the oldest preserved relic icons, three icons and the Grand Cross of the former iconostasis, the work of talented descendants of the famous painter of the 16th century Onuphrius. The monastery flourished during its Abbot Archimandrite Arseny, when it got its present distinctive character of two monastery wings: on the east - three-storey Upper Palace built in 1814, which houses the monastic cells, and on the west side - the double monastery dinning built in 1820-1825. The striking artwork of wood carved iconostasis and painted decoration in the men's dining room was created at the time of the Archimandrite and immediately after his death. The authors of the iconostasis doors, the Episcopal throne and the Abbot chair are the famous carvers of Mijacki woodcarving group: Petre FilipovicGarkata, Makarie Frchkovski from Galichnik, Dimitar Stanichev from Krusevo, and several assistants from villages. In 1835, they completed work on the monumental three-storey iconostasis, the bishop and the abbot chair for which they were paid 18,384 pennies by Abbot Arseny. 
The royal doors are similar to the ones previously made in Lesnovo Monastery and the Church of the Holy Saviour.

Lesnovo Monastery. The monastery was dedicated to St. Archangel Michael and built in an old cult place where St. Hermit Gabriel Lesnovski, one of the most famous South Slavic hermits, lived and was buried in 11-12 century. Strong hermit cult contributed that Lesnovo has dual representation - Archangel Michael and St. Lesnovski. The monastic complex known today was founded by Despot Jovan Oliver, a high nobleman from the time of Serbian King Stefan Dusan. The royal door in the centre of iconostasis is made in deep woodcarving by Petre Filipovic-Garkata from 1811 to 1814 . The doors were originally gilded, later covered with bronze paint. The grapes from the vines are coloured purple and red. Lesnovo Monastery is significant for the history of the Slavic literacy and literature. A great many manuscripts and printed books from the famous scriptorium were taken abroad in the 19th century and are kept in the libraries of other countries. Although buildings and wall paintings from the 16th and 17th centuries are not preserved, this rich period in the monastery history is illustrated by icons, which are museum exhibits. The carved iconostasis from 1814 is the work of the virtuous masters led by Petre Filopovski-Garkata and icons made in that period were painted by Samokov School painters.

\section{CONCLUSION}

The presented churches and monasteries are some of the most significant religious sites in the Republic of Macedonia, important shrines for the Orthodox Christian population and places with rich spiritual values. The sites are distinguished by attractive attributes that increase their tourism value, such as: architectural value of buildings, artistic value of iconostases and frescos, cultural and historical values. The religious buildings can undoubtedly contribute to tourism development in the country, in particular as the material basis for the religious tourism, which has the potential to enrich, improve or complete the existing tourism offer.

\section{REFERENCE}

Budinoski, M. (2009). Tourism, principles and practices. Skopje: ANFI.

Hrabovski-Tomic, E. (2008). Selective forms of tourism. Sremska Kamenica: FABUS.

Kohl \& Partner. (2015). National Strategy for Tourism of the Republic of Macedonia. Skopje

Ministry of Culture of the Republic of Macedonia. (2012). List of protected goods. Administration for Protection of Cultural Heritage. Skopje.

Panov, N. (2006). Basics of Tourism. Skopje: FOIK

Statistical Review: Transport, tourism and other services. (2013). State Statistical Office of the Republic of Macedonia: Skopje. 